\title{
The influence of lens material and lens wear on the removal and viability of Staphylococcus epidermidis
}

\author{
Lívia Santos $^{\mathrm{a}}$, Diana Rodrigues ${ }^{\mathrm{a}}$, Madalena Lira ${ }^{\mathrm{b}}$, M. Elisabete C.D. Real Oliveira ${ }^{\mathrm{b}}$, \\ Rosário Oliveira $^{\mathrm{a}}$, Eva Yebra-Pimentel Vilar ${ }^{\mathrm{c}}$, Joana Azeredo ${ }^{\mathrm{a}, *}$ \\ ${ }^{a}$ IBB - Institute for Biotechnology and Bioengenhary, Centre of Biological Engineering, University of Minho, Braga, Portugal \\ ${ }^{\mathrm{b}}$ Centre of Physics (Optometry), University of Minho, Braga, Portugal \\ ${ }^{c}$ Departments of Optics and Optometry, University of Santiago of Compostela, Santiago of Compostela, Spain
}

\begin{abstract}
Purpose: The aim of this study was to evaluate the influence of lens material and lens wear on the removal capability of Staphylococcus epidermidis. Assessment of viability of remaining adhered bacteria was another goal of this work. Four silicone hydrogel materials (galyfilcon A, balafilcon A, lotrafilcon A, lotrafilcon B) and one conventional hydrogel material (etafilcon A) were assayed.

Methods: Detachment studies on S. epidermidis were carried out in a parallel plate flow chamber. Contact lenses (CLs) were fitted to the bottom of the flow chamber and a bacterial suspension was perfused into the system, promoting bacterial adhesion. Afterwards, detachment was stimulated using a multipurpose solution (MPS, ReNu Multiplus ${ }^{\mathbb{R}}$ ) and the percentage of removed bacteria estimated through microscopic observation and enumeration. Remaining adhered bacteria were stained with propidium iodide (PI) and enumerated in order to assess their viability. Additionally, the worn lenses were observed by confocal laser scanning microscopy (CLSM) to visualize bacterial distribution along the lens surfaces.

Results: Bacterial removal was significant $(p<0.05)$ for both unworn and worn galyfilcon A and etafilcon A. Galyfilcon A exhibited a detachment percentage of 59.1 and 63.5 while etafilcon A of 62.6 and 69.3, both for unworn and worn lenses, respectively. As far as bacterial viability is concerned, it was found that worn lenses exhibit a superior amount of non-viable bacteria than unworn CLs. Images obtained by CLSM revealed an irregular bacterial distribution for all lens materials.

Conclusions: It appears that surface and/or bulk structure of the lens material affects removal of S. epidermidis while CL wear influences their viability.

(C) 2008 British Contact Lens Association. Published by Elsevier Ltd. All rights reserved.

Keywords: Bacterial detachment; Silicone hydrogel; Cell viability
\end{abstract}

\section{Introduction}

CL solutions were first produced in the late 40s and have been developed ever since. These solutions should comprise several functions as to enhance CL wettability, prevent the build-up of deposits and provide effective disinfection against pathogenic microorganisms [1]. Currently, MPS are the most popular CL solutions since they permit in a single

\footnotetext{
* Corresponding author at: Departamento de Engenharia Biológica, Campus de Gualtar, 4710-057 Braga, Portugal. Tel.: +351 253 604400; fax: +351 253678986

E-mail address: jazeredo@deb.uminho.pt (J. Azeredo).
}

step to clean, rinse and disinfect [2]. Disinfection is mainly promoted by the presence of biocides and it is essential to prevent ocular infections, which ultimately can lead to vision impairment. This process may be affected by numerous factors, which include the biocide, the challenging microbe, the material and the presence of organic matter [3-6]. Due to the presence of surfactants, MPS may also promote bacterial removal; however, according to a previous study it was not significant [7].

Polyhexamethylene biguanide (PHMB) is one of the most popular biocide agents and has been used since the mid $70 \mathrm{~s}$ in ophthalmic solutions. It is a polymeric cationic surfactant that belongs to the biguanide family and is 
currently used in several commercially available MPS. PHMB performs by enabling membrane disruption and lysis in bacteria, which results in their death $[8,9]$.

Several studies have investigated disinfection and bacterial detachment from CLs [7,10-17]. However, since silicone hydrogel CLs were launched, very few works have been performed with this type of material. The present study aimed to evaluate the influence of lens material and lens wear on the detachment capability of Staphylococcus epidermidis. Four silicone hydrogel materials (galyfilcon, balafilcon A, lotrafilcon A, lotrafilcon B) and one HEMA material (etafilcon A) were worn daily, for one month with nightly disinfection with a single multipurpose solution (ReNu Multiplus). In addition, viability and distribution of the remaining adhered bacteria were analysed through epifluorescence microscopy and CLSM, respectively. Matched unworn lenses served as the control.

\section{Materials and methods}

\subsection{Contact lenses}

The CLs used in this study are detailed in Table 1.

\subsection{Clinical trial}

Thirty-one subjects from both genders enrolled the present study, excluding any lost to follow up. The volunteers were predominantly from the north of Portugal and the average age was $23.6 \pm 5.5$ years. These were chosen according to the following parameters: they have never worn CLs before (neophytes), they were not taking any medications during the trial, they did not suffer from any kind of ocular allergy and they had no tendency for dry eye syndrome.

Subjects were divided into four groups. Eight individuals were fitted with galyfilcon $\mathrm{A}$, eight with balafilcon $\mathrm{A}$, eight with lotrafilcon A and seven with lotrafilcon B. Etafilcon A was used as contralateral pair into the four groups since a parallel study was ongoing in order to evaluate morphological changes between one eye fitted with a silicone hydrogel and the other fitted with a conventional hydrogel. According to the manufactures' recommendations, one of the silicone hydrogel lenses, galyfilcon $\mathrm{A}$ wear is recommended under a two-week planned replacement modality. However, in this study, it was worn for 30 days in order to establish a comparison with the other silicone hydrogel lenses. None of the groups was aware of the CL material or brand they were using.

Silicone hydrogel CLs were used during 30 days and etafilcon A for 15 days (replaced at the end of 15 days), according to a daily wear schedule. The subjects were instructed to remove their lenses and place them directly into a solution (ReNu MultiPlus ${ }^{\circledR}$, Bausch \& Lomb, Inc. polyhexanide $0.0001 \%$, hydranate $0.03 \%$ and poloxamine $1 \%$ ) for overnight disinfection, between 12 and $14 \mathrm{~h}$ wear (no rub or rinse). At the end of the wearing period, each lens was aseptically removed from the eye and placed in a sterile vial containing a sterile saline solution $(0.9 \% \mathrm{NaCl})$. Vials were labelled with a code and details of the lens material. The CLs were stored at $4{ }^{\circ} \mathrm{C}$ no longer than 5 days until analysis. Unworn CLs were stored at room temperature $\left(20^{\circ} \mathrm{C} \pm 2\right)$ and managed under sterile conditions until the beginning of experiments.

Each subject signed an informed consent following an explanation related to the nature of the study and its possible risks to the participant. No significant adverse events occurred throughout the course of this study.

\subsection{Microorganism and growth conditions}

The challenging microorganism was $S$. epidermidis 9142. This Gram-positive bacterium is a clinical isolate and was kindly provided by Dr. Gerald B. Pier, Harvard Medical School, Boston, USA. Its adhesion and biofilm formation capabilities were characterised in a previous study [18].

A $4{ }^{\circ} \mathrm{C}$ culture stock was inoculated into an Erlenmeyer flask containing $10 \mathrm{ml}$ of tryptic soy broth (TSB, Merck, Germany) and incubated for $24 \mathrm{~h}$ at $37^{\circ} \mathrm{C}$. After this period, $1 \mathrm{ml}$ of the culture suspension was transferred to a second Erlenmeyer flask containing $30 \mathrm{ml}$ of TSB and incubated for $18 \mathrm{~h}$ at $37^{\circ} \mathrm{C}$ in order to obtain a mid-exponential growth culture. Cells were harvested by centrifugation $(15 \mathrm{~min}$, $4000 \mathrm{rpm}$ ) and washed twice with ultrapure water. Finally, the cells were resuspended in phosphate buffer saline (PBS, $8 \mathrm{~g}^{-1} \mathrm{NaCl} 0.2 \mathrm{~g} \mathrm{l}^{-1} \mathrm{KCl} 0.2 \mathrm{~g} \mathrm{l}^{-1} \mathrm{KH}_{2} \mathrm{PO}_{4} 1.15 \mathrm{~g} \mathrm{l}^{-1}$ $\mathrm{Na}_{2} \mathrm{HPO}_{4} \mathrm{pH}$ 7.4) and the concentration adjusted to $6 \times 10^{10} \mathrm{CFU} / \mathrm{ml}$.

Table 1

Contact lenses properties

\begin{tabular}{|c|c|c|c|c|c|}
\hline Commercial name & Manufacturer & Material & FDA group & Water content $(\%)$ & Surface treatment \\
\hline Acuvue $^{\circledR}$ & Johnson \& Johnson Vision Care & Etafilcon A & IV & 58 & No \\
\hline Acuvue $^{\circledR}$ Advance $^{\mathrm{TM}}$ & Johnson \& Johnson Vision Care & Galyfilcon & I & 47 & No \\
\hline Purevision $^{\mathrm{TM}}$ & Bausch \& Lomb, Inc. & Balafilcon A & III & 36 & Plasma oxidation \\
\hline Focus ${ }^{\circledR}$ Night $\&$ Day $^{\mathrm{TM}}$ & CIBA Vision & Lotrafilcon A & I & 24 & $\begin{array}{l}25 \mathrm{~nm} \text { plasma coating with } \\
\text { high refractive index }\end{array}$ \\
\hline $\mathrm{O}_{2} \mathrm{Optix}{ }^{\mathrm{TM}}$ & CIBA Vision & Lotrafilcon B & I & 33 & $\begin{array}{l}25 \mathrm{~nm} \text { plasma coating with } \\
\text { high refractive index }\end{array}$ \\
\hline
\end{tabular}




\subsection{Detachment experiments}

Prior to detachment studies, bacterial adhesion was induced by perfusing a bacterial suspension throughout the system during $120 \mathrm{~min}$. CLs were fitted to the bottom of the flow chamber and all tubes filled with PBS, which circulated for $15 \mathrm{~min}$. After this period, PBS was switched for the bacterial suspension previously prepared as described in Section 2.3. The suspension flowed throughout the system for $120 \mathrm{~min}$ with a flow rate of $2 \mathrm{E}-4 \mathrm{ml} / \mathrm{s}$, at room temperature. Fresh PBS was then recirculated throughout the system in order to remove the non-adhered or loosely adhered cells. Each CL was observed under phase contrast microscopy and twenty pictures (CCD video camera, Carl Zeiss, Germany) were taken with special care to cover both central and peripheric areas of the lens. Magnification of $1622 \times$ and a resolution of 1300 pixel $\times 1030$ pixel was used. The pixel area of each image was 2,62,144 pixels ${ }^{2}$ and corresponds to $1.96 \mathrm{E}-4 \mathrm{~cm}^{2}$. Detachment experiments were initiated after capturing images of initially adhered cells.

In order to keep the same hydrodynamic conditions used in the adhesion step, detachment studies were also carried out in the parallel plate flow chamber. The authors are aware that dynamic systems do not reproduce the soaking process normally performed in CL disinfection; however, the goal of this study was mainly to assess cell removal.

Bacterial detachment was stimulated by perfusing the system with the MPS (ReNu MultiPlus ${ }^{\circledR}$, Bausch \& Lomb, Inc.) for $120 \mathrm{~min}$. Again, twenty pictures (CCD video camera, Carl Zeiss, Germany) were taken with special care to cover both central and peripheric areas of the lens. Magnification of $1622 \times$ and a resolution of 1300 pixel $\times 1030$ pixel was used. The pixel area of each image was $2,62,144$ pixels $^{2}$ and corresponds to $1.96 \mathrm{E}-4 \mathrm{~cm}^{2}$.

The percentage of bacterial removal was calculated as follows:

$$
\begin{aligned}
& \% \text { Removal } \\
& =\left(\frac{\text { adhered cells }- \text { adhered cells after MPS action }}{\text { adhered cells }}\right) \\
& \quad \times 100
\end{aligned}
$$

\subsection{Bacterial viability}

Viability of adhered bacteria to worn lenses was investigated through propidium iodide (PI) (Sigma-Aldrich, Germany), staining $\left(5 \mu \mathrm{g} \mathrm{ml}^{-1}\right)$, followed by epifluorescence microscopy observation and cell enumeration.

This fluorochrome is capable of staining nucleic acids when the cellular membrane is disrupted and therefore was used to assess cell viability [19]. It was expected that PHMB as well as lytic proteins (present in the tear film) would bind to the outermost surface of bacterial cells disrupting them. Membrane disruption followed by leakage of the inner cellular compounds should open a pathway for PI linkage to the nucleic acids.

After bacterial detachment, each CL was covered with a few drops of the dye. They were incubated in the dark for $1 \mathrm{~min}$ and then observed through an epifluorescence microscope (Carl Zeiss, Germany) coupled to a CCD video camera (Carl Zeiss, Germany). The excitation and emission wavelengths were 530 and $615 \mathrm{~nm}$, respectively. Twenty pictures of the adhered bacteria were taken with special care to cover both central and peripheric areas of the lens. The magnification and resolution used were the same as for contrast phase microscopy. Afterwards, the non-viable cells were enumerated.

The percentage of non-viable cells remaining adhered to the lens surface was calculated as follows:

$$
\begin{aligned}
& \% \text { Non-viable cells } \\
& =\left(\frac{\text { adhered non viable cells }}{\text { adhered cells after MPS action }}\right) \times 100
\end{aligned}
$$

Non-viable bacteria were also observed by CLSM (FV 1000 Fluoview, Olympus Europa GMBH, Germany) through a three-dimensional image of adhered bacteria and their distribution along the lens surface.

\subsection{Statistical analysis}

Bacterial removal was analysed through the nonparametric Mann-Whitney $U$ Test. All tests were performed with $95 \%$ confidence level using the statistical program SPSS (Statistical Package for the Social Sciences).

\section{Results}

\subsection{Bacterial detachment}

The percentage of removed bacteria is detailed in Table 2 . According to statistical analysis, bacterial removal was significant for galyfilcon A and etafilcon A materials. Both unworn galyfilcon A and etafilcon A showed $p=0.029$, while worn galyfilcon A and etafilcon A exhibited $p=0.006$ and $p<0.001$, respectively.

\subsection{Cell viability}

Table 2 also presents the percentage of non-viable cells that remained adhered after the passage of the MPS. This percentage was higher for worn CL, ranging from $23.0 \%$ $\left(3.50 \mathrm{E} 5 \mathrm{cells} / \mathrm{cm}^{2}\right)$ to $72.3 \% \quad\left(1.86 \mathrm{E} 6\right.$ cells $\left./ \mathrm{cm}^{2}\right)$ while unworn ones ranged from $12.3 \%\left(1.19 \mathrm{E} 5 \mathrm{cells} / \mathrm{cm}^{2}\right)$ to $27.5 \%\left(4.33 \mathrm{E} 5 \mathrm{cell} / \mathrm{s} / \mathrm{cm}^{2}\right)$. It was not possible to visualize stained bacteria adhered to unworn etafilcon A.

Images obtained by CLSM are present in Fig. 1. These images show an irregular dispersion of bacteria along the CL surfaces. Lotrafilcon B CL was not subjected to such 
Table 2

Percentage of cell removal and non-viable $S$. epidermidis adhered to unworn and worn contact lenses

\begin{tabular}{llllll}
\hline & \multicolumn{2}{l}{ Unworn lenses } & & \multicolumn{2}{l}{ Worn lenses } \\
\cline { 2 - 3 } \cline { 5 - 6 } & $\begin{array}{l}\text { \% Cell } \\
\text { removal }\end{array}$ & $\begin{array}{l}\text { \% Non- } \\
\text { viable } \\
\text { cells }\end{array}$ & & $\begin{array}{l}\text { \% Cell } \\
\text { removal }\end{array}$ & $\begin{array}{l}\text { \% Non- } \\
\text { viable } \\
\text { cells }\end{array}$ \\
\hline Galyfilcon A & $59.06^{\mathrm{a}}$ & 12.28 & & $63.46^{\mathrm{a}}$ & 33.92 \\
Balafilcon A & 57.78 & 6.61 & & 44.22 & 60.55 \\
Lotrafilcon A & 38.07 & 24.63 & & 50.43 & 47.06 \\
Lotrafilcon B & 39.10 & 27.49 & & 14.13 & 72.74 \\
Etafilcon A & $62.63^{\mathrm{a}}$ & 0 & & $69.29^{\mathrm{a}}$ & 23.04 \\
\hline
\end{tabular}

a Statistically significant (Mann-Whitney $U$ with 95\% confidence level).

analysis due to their surface treatment similarity with lotrafilcon A.

\section{Discussion}

The present study investigated the influence of lens material and wear on the removal and viability of adhered $S$. epidermidis to silicone and conventional hydrogel CL. A single PHBM-based solution was used. S. epidermidis is a pathogen normally associated to device-related infections and thus it was considered an appropriate challenging microorganism [20-22]. Bacterial disinfection and detachment are two different concepts, but both important from a clinical perspective. While disinfection typically involves cell lysis and death, bacterial detachment promotes cell removal from the lens surface.

Detachment studies revealed that bacterial removal was significant from galyfilcon $\mathrm{A}$ and etafilcon A materials (Table 2). This result was obtained either for unworn or for worn lenses. Galyfilcon A and etafilcon A are made by the same manufacturer and are the only ones that do not have surface treatment. Although surface treatment improves surface wettability, it also adds chemical active groups [23] and seems to enhance roughness [24]. These factors might have increased the interaction between the CL and the bacteria making their removal more difficult. This seems to be true, because in this work surface-treated CLs did not show significant cell removal. We also address the hypothesis that PHMB could be operating on the lens surface rather than within the matrix, resulting in a large degree of bacterial removal for galyfilcon A and etafilcon A. PHMB contained in ReNu Multiplus is a large dimensional molecule and its size could limit its adsorption into the lens matrix [25]. This seems especially consistent for etafilcon A, which possesses small pores [26]. Although few data have been published about this material, it seems plausible that galyfilcon A structure and porosity could also have limited PHMB adsorption. This assumption is based on a study in which the ultra-structure of balafilcon A, lotrafilcon A and galyfilcon A was investigated using Cryo-SEM [27]. The authors found that balafilcon A and lotrafilcon A materials exhibit what appears to be a loose network, while galyfilcon A shows a solid bulk. Even though unworn balafilcon A and worn lotrafilcon A exhibited levels of bacterial removal near to the observed for galyfilcon A or etafilcon A, they were not significant from a statistical perspective. Still, we believe that these results could be clinically relevant and thus they should not be disregarded.

The determination of the amount of non-viable bacteria remaining adhered is of great clinical importance. This study reveals that although these cells remained adhered after the detachment procedure, they were inactive and thus virtually not harmful. Bacterial viability was assessed with the fluorescence dye PI. This assessment is usually made by the classic method of colony forming units (CFU). The CFU method involves total bacterial removal from the lens surface followed by agar platting and counting after $48 \mathrm{~h}$ of incubation. The main disadvantage is that the removal process can kill bacterial cells through excessive vortexing
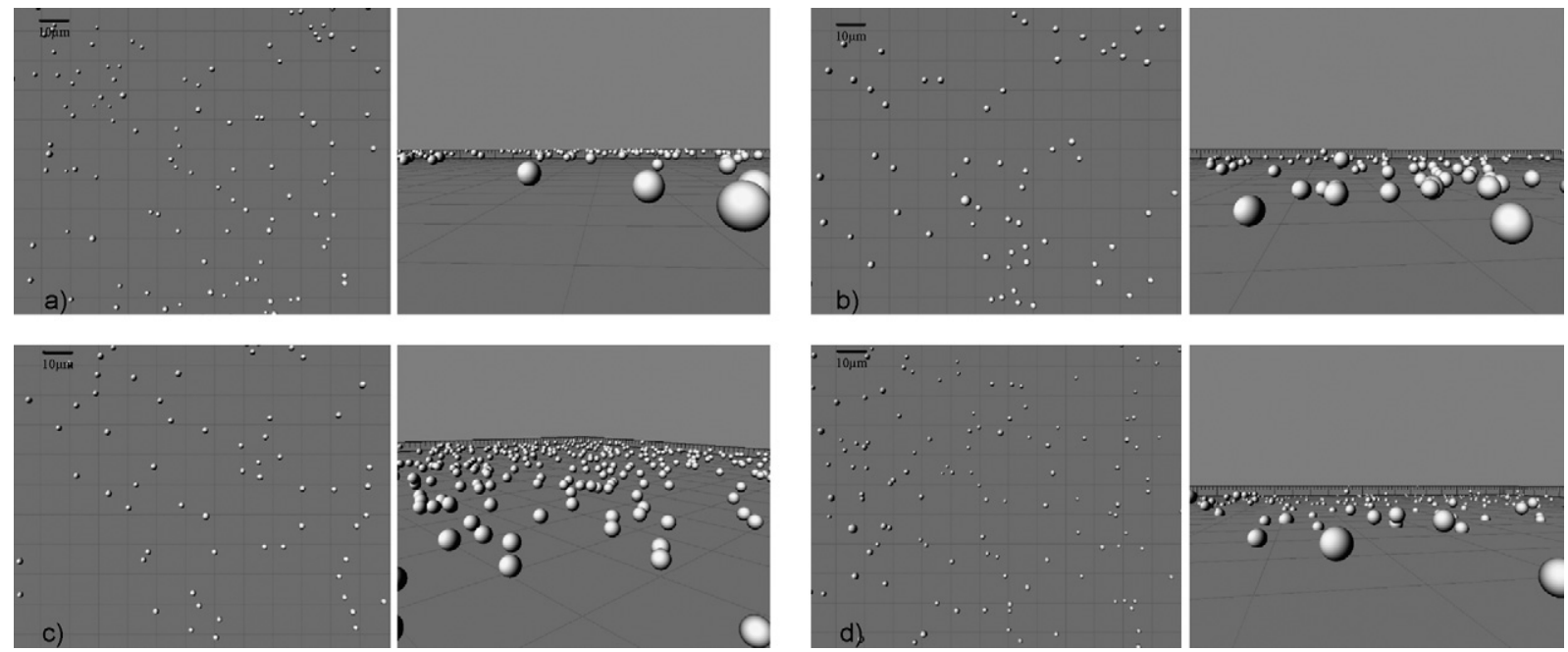

Fig. 1. Top and perspective images obtained through CLSM of S. epidermidis adhered to worn galyfilcon A (a), balafilcon A (b), lotrafilcon A (c) and etafilcon A (d). 
or sonication, or not removing all adhered bacteria. PI staining not only allows in situ cell enumeration, but is also a faster and reliable method [13]. The results (Table 2) show that worn lenses contain a greater percentage of non-viable bacteria than unworn ones. It is generally accepted that lens wear induces the adsorption of lysozyme and lactoferrin, which are bacteriolytic proteins [28,29]. Therefore, their presence on the lens surface may induce bacterial lysis resulting in this higher percentage of non-viable cells. Indeed, a similar result was previously reported by Williams et al. [30], who suggested that lactoferrin killed the attached bacteria on worn lenses. To some extent, we agree that daily $\mathrm{CL}$ maintenance with ReNu Multiplus might have assisted this result.

CLSM is a valuable imaging method, which allows living and dead cells observation. Several scans above the lens surface permit a detailed three-dimensional image of adhered bacteria. It is possible to observe (Fig. 1) that $S$. epidermidis is irregularly distributed among all lens surfaces, which seems related with the presence of deposited tear film as this assay was performed on worn lenses.

\section{Acknowledgements}

The authors fully acknowledge the financial support of the Portuguese Foundation for Science and Technology (FCT) through the project POCTI/FCB/44628/2002 and also the grant BD 19679/2004 (FCT).

\section{References}

[1] Jones L, Senchyna M. Soft contact lens solution review. Part 1. Components of modern care regimens. Optom Pract 2007;8:XX.

[2] Rakow PL. Current contact lens care systems. Ophthalmol Clin North Am 2003;16:415-32.

[3] Baker F, Breach M. Antiseptics and disinfectants. Methods Enzymol 1987;2:61-8.

[4] Russell AD. Biocide and antibiotic resistance: the relevance of laboratory findings to clinical and environmental situations. Infect Dis 2003;3:794-803.

[5] Russell AD. Similarities and differences in the responses of microrganisms to biocides. J Antimicrob Chemother 2003;52:750-63.

[6] Russell AD. Bacterial adaptation and resistance to antiseptics, disinfectants and preservatives is not a new phenomenon. J Hosp Infect 2004;57:97-104.

[7] Landa AS, van der Mei HC, van Rij G, Busscher HJ. Efficacy of ophthalmic solution to detach adhering Pseudomonas aeruginosa from contact lenses. Cornea 1998;17:293-300.

[8] Gilbert P, Moore LE. Cationic antiseptics: diversity under a common epithet. J Appl Microbiol 2005;99:703-15.

[9] Maillard J-Y. Bacterial target sites for biocide action. J Appl Microbiol Symp Suppl 2002;92:16S-27S.

[10] Borazjani RN, May LL, Noble JA, Avery NS, Aheran DG. Flow cytometry for determination of the efficacy of contact lens disinfection solutions against Acanthamoeba spp.. Appl Environ Microbiol 2000;66:1057-61.

[11] Codling CE, Hann AC, Maillard JY, Russell AD. An investigation into the antimicrobial mechanisms of action of two contact lens biocides using electron microscopy. Contact Lens Anterior Eye 2005;28:163-8.

[12] Dannelly HK, Waworuntu RV. Effectiveness of contact lens disinfectants after lens storage. Eye Contact Lens 2004;30:163-5.

[13] Gavin J, Button NF, Watson Craik IA, Logan NA. Observation of soft contact lens disinfection with fluorescent metabolic stains. Appl Environ Microbiol 2000;66:874-5.

[14] Hume EBH, Zhu H, Cole N, Huynh C, Lam S, Willcox MDP. Efficacy of contact lens multipurpose solutions against Serratia marcescens. Optom Vis Sci 2007;84:316-20.

[15] Lakkis C, Fleiszig SMJ. Resistance of Pseudomonas aeruginosa isolates to hydrogel contact lens disinfection correlates with cytotoxic activity. J Clin Microbiol 2001;39:1477-86.

[16] Rosenthal RA, Henry CL, Schlech BA. Contribution of regimen steps to disinfection of hydrophilic contact lenses. Contact Lens Anterior Eye 2004;27:149-56.

[17] Santodomingo-Rubido J, Mori O, Kawaminami S. Cytotoxicity and antimicrobial activity of six multipurpose soft contact lens disinfecting solutions. Ophthal Physiol Opt 2006;26:476-82.

[18] Cerca N, Pier GB, Vilanova M, Oliveira R, Azeredo J. Quantitative analysis of adhesion and biofilm formation on hydrophilic and hydrophobic surfaces of clinical isolates of Staphylococcus epidermidis. Res Microbiol 2005;156:506-14.

[19] Tas J, Westerneng G. Reagent for the fluorescent staining of nucleic acids. J Histochem Cytochem 1981;29:929.

[20] Götz F. Staphylococcus and biofilms. Mol Microbiol 2002;43:136778.

[21] Götz F. Staphylococci in colonization and disease: prospective targets for drugs and vaccines. Curr Opin Microbiol 2004;7:477-87.

[22] Gristina AG, Naylor PT. Implant-associated infection. In: Ratner BD, Hoffman AS, Schoen FJ, Lemons JE, editors. Biomaterials ScienceAn Introduction to Materials in Medicine. Academic Press; 1996. p. 205-14.

[23] Packham DE. Surface energy, topography and adhesion. Int J Adhes Adhes 2003;23:437-48.

[24] Guryča V, Hobzová R, Pøádny M. Surface morphology of contact lenses probed with microscopy techniques. Contact Lens Anterior Eye 2007.

[25] Tonge S, Tighe B, Franklin V. Contact lens care. Part 5. The design and wetting of multipurpose solutions. Optician 2001;222:22-8.

[26] López-Alemany A, Compañ V, Refojo MF. Porous structure of Purevision $^{\mathrm{TM}}$, versus Focus $\mathbb{B}$ Night\&Day ${ }^{\mathrm{TM}}$ and conventional hydrogel contact lenses. J Biomed Mater Res Part B: Appl Biomater 2002;63: 319-25.

[27] González-Méijome JM, López-Alemany A, Almeida JB, Parafita MA, Refojo MF. Microscopic observations of superficial ultrastructure of unworn siloxane-hydrogel contact lenses by cryo-scanning electron microscopy. J Biomed Mater Res Part B: Appl Biomater 2007;76B: 419-23.

[28] Santos L, Rodrigues D, Lira M, Real Oliveira MECD, Oliveira R, Vilar EY-P, et al. The influence of surface treatment on hydrophobicity, proteins adsorption, and microbial colonisation of silicone hydrogel contact lenses. Contact Lens Anterior Eye 2007;30:183-8.

[29] Sariri R. Protein interaction with hydrogel contact lenses. J Appl Biomater Biomech 2004;2:1-19.

[30] Williams TJ, Willcox MDP, Schneider RP. Interactions of bacteria with contact lenses: the effect of soluble protein and carbohydrate on bacterial adhesion to contact lenses. Optom Vis Sci 1998;75: 266-71. 